\title{
Balkanologie
}

Balkanologie Revue d'études pluridisciplinaires

Vol. $15 n^{\circ} 1 \mid 2020$

Mémoires performatives : faire des passés et des présents

\section{On the better angels of anthropology: A few words to a friend missing and missed}

Slobodan Naumović

\section{(2) OpenEdition}

\section{Journals}

Electronic version

URL: https://journals.openedition.org/balkanologie/2468

DOI: $10.4000 /$ balkanologie.2468

ISSN: 1965-0582

\section{Publisher}

Association française d'études sur les Balkans (Afebalk)

\section{Electronic reference}

Slobodan Naumović, "On the better angels of anthropology: A few words to a friend missing and missed", Balkanologie [Online], Vol. 15 n 1 | 2020, Online since 01 June 2020, connection on 05 August 2021. URL: http://journals.openedition.org/balkanologie/2468 ; DOI: https://doi.org/10.4000/ balkanologie. 2468

This text was automatically generated on 5 August 2021.

(c) Tous droits réservés 


\title{
On the better angels of anthropology: A few words to a friend missing and missed
}

\author{
Slobodan Naumović
}

1 I want to share a few words about a colleague and friend, missing and missed. It is from him that I learned more about anthropology's once central and nowadays almost neglected key topic - humanity and humanism - than I did from most of my formal teachers.

2 It now seems to me that Vintilă Mihăilescu and I started our friendship long before we actually met. For the past is a foreign country that we try to interpret with tools forged only in the present. As my memory chooses to present the past to me, many years ago on a train to Thessaloniki, a dear colleague mentioned a Romanian anthropologist with a tricky name, insisting that I should meet him. It so happened that soon after that trip I got hold of a copy of the journal Terrain, with a text on nationalism by Vintilă in it. I don't remember the details any more, but I do remember that I felt as if there were added value to every word I read. My memory wishes to tell me that it was then that we became friends. The impression that there was an additional layer of meaning to everything that Vinita said or wrote, not always consistent with what most of his interlocutors believed was initially intended, never left me from that very day. Anthropology is, after all, about managing complexity, and so is humanity.

3 As time went on, and with it the conferences and projects which brought us together again and again, I got used to the fact that there were times when Vintilă was almost as surprised as his interlocutors were by the full implications of what he was about to say. The meandering, nonlinear way in which he spoke (and thought) drove quite a few project managers (and some colleagues) furious. Vintilă's kind and unaggressive manners and exquisite personal charm did much to ease the frictions which his brilliance and originality often managed to cause. So did his looks. With an elongated face, a greying beard and long hair, as if he were a saint from an Orthodox icon, and with his flowery shirts and leather vests, he looked as if he came from a very foreign 
country or from the distant past. As it seemed to many, such a person simply could mean no harm.

Vintilă's mind was particularly sensitive to the specificities of the spaces in which the intellectual exchanges so important to him took place. The silent taverna under the megalos platanos (great plain tree) in a deserted mountain village in the Pindus Mountains overlooking the plains of the Aoos River made him tranquil and dignified, sparse with words, so that each one he uttered shone with a multitude of hints and connotations. However, at such solemn places, the sounds of silence and the expressions of his saintly face became Vintilă's loudest words. The somewhat snobbish, deliberately shabby, and artistic attic-like den called the Hambara, probably the most famous "hidden" bar of the Bulgarian capital Sofia, tucked in the backyard of a residential building, brought about a different Vintilă. Much more youthful in disposition and daring to savor new sensations like the medicinal taste of the Lagavulin, an Islay single malt he once swore never to try, Vintilă became talkative and ironic, ready to pull away the carpets beneath people's personal identity myths, and hastily clad theoretical constructs. In places like the Hambara, a chatty and snappy Vintilă replaced the solemn, pensive, silent one from the mountains. Still closer to his hometown Bucharest, in a sheep-herding village in the proximity of the late medieval walled town of Sibiu, Vintilă slipped into the proverbial role of the field-guru. Why not remain in the village, instead of returning with the bus to the safety of "civilization", he would ask? Why not meet the shabby but devilishly strong peasants who own thousands of sheep but drive around in rotting Dacias? Why not taste their strong sheep-milk cheese, and drink their even stronger Țuică till our brains softened and our tongues loosened up, and we started going to the heart of the matter, and far beyond it, in the pink mists just before daylight? And why not try to stand up to what the Transylvanian Other might see in you by the flickering candlelight, when smart words can't help you look brighter and better than you really are? Another Vintilă dwelt in this Field, the proverbial rough home of the "true" anthropologist, and he had no mercy for the pettiness and weaknesses of spoiled urbanites, even though he used to be one himself. Yet another Vintilă loomed in the 4.5-metre-high rooms of the somewhat decadent German villa serving as the guesthouse of the Max Planck Institute for Social Anthropology in Halle/Saale. This brand of Vintilă was a polyglot and savvy polymath, master of the latest anthropological fads and fashions, as distant as possible from the heart of darkness of his Transylvanian and Danubian field sites, and as polite and cultured as any member of the old Central European intelligentsia ever was. This was the Vintilă that most colleagues will remember, and for good reasons. For it is this Vintilă who embodied what Blaise Pascal once termed as l'esprit de finesse. This phrase, sometimes defined as the opposite of l'esprit de géométrie, was used by Pascal to designate "la capacité intuitive de l'Homme utilisant davantage ses sentiments que sa raison."

However, Vintilă's esprit de finesse was a cloak under which there were still other Vintilăs, and among them, one that only two people came to know. This one was the Vintilă who lit a tiny candle in a glass cup on the top of his head to honour the good angel he believed was guarding him. He did it in a restaurant in Sofia, perhaps the last one that was open that night. This was Vintilă the mystic, the most enigmatic of them all, and perhaps the dearest to me. For in him, there was intuition that transcended the conventional, and there was faith, love, and so much goodwill for all humankind - and for everything - all that represents the better angels of anthropology. I believe this symbolic act - the lighting of the candle for a better angel - to be Vintilă's most 
important lesson. It was meant to demonstrate that there is so much more to us as humans, and as anthropologists, than can be grasped by l'esprit de géométrie. We desperately need today l'esprit de finesse if we are to keep in touch with the better angels of our nature as our world is crumbling around us.

Even if the little flame that Vintilă once lit was extinguished years ago, and even if his guardian angel did finally desert him, and even if he himself is now gone, Vintilă and his better angels are still with us, and will be always. For it is through their symbolic acts, which we refuse to forget, that those dear to us keep living on, and it is with the help of the many good people who make such acts possible, that we eventually manage to become what we should have been from the very start.

Let me finish by sharing the last emails that we exchanged:

Date: Monday, December 24, 2018, 3:54 PM

Dear Vintila,

I was thinking of you intensively last month....

We have to meet again and sit under the platanos tree in the deserted village overseeing the mountains and the skyline.

Then I heard from Ioannis Manos that your dark visitor returned.

I remember your angel very well, and how strong your bond is, and I know he will find a way to make the visitor go away again....

So, here's to the angels and to all that they make possible - and here's to the joy of life (of which you are such a master), without which all the miracles are in vain! I think of you and love you, Vintila.

Slobodan

Dear Slobodan,

Many thanks and be sure I'll overcome, our debate about angels (with Petya ${ }^{1}$ as judge!) has to go on!

I also think of you in special moments of my life, it seems that there is something special about our friendship!...

Best,

Vintila

\section{NOTES}

1. Vintila is referring here to Petya Kabakchieva.

\section{AUTHOR}

\section{SLOBODAN NAUMOVIĆ}

Department of Ethnology and Anthropology, University of Belgrade 